\title{
Sciendo
}

HOLISTICA Vol 10, Issue 2, 2019, pp. 23-38

\section{Investor behavior based on personality and company life cycle}

\author{
Elizabeth Lucky Maretha, SITINJAK, \\ Soegijapranata Catholic University of Economics \& Business Faculty, \\ Pawiyatan Luhur IV/ 1 Bendan Duwur, Semarang-Indonesia \\ lucky@unika.ac.id \\ Kristiana, HARYANTI, \\ Soegijapranata Catholic University of Psychology Faculty, \\ Pawiyatan Luhur IV/ 1 Bendan Duwur, Semarang-Indonesia, \\ kristiana@unika.ac.id \\ Widuri, KURNIASARI, \\ Soegijapranata Catholic University of Economics \& Business Faculty, \\ Pawiyatan Luhur IV/ 1 Bendan Duwur, Semarang-Indonesia \\ widuri@unika.ac.id \\ Yohanes Wisnu Djati, SASMITO, \\ Soegijapranata Catholic University of Economics \& Business Faculty, \\ Pawiyatan Luhur IV/ 1 Bendan Duwur, Semarang-Indonesia \\ wisnu@unika.ac.id
}

\begin{abstract}
This study aims to ensure that the behavior of individual stock investors has the best pattern in accordance with the existing personality, and see the business cycle starting from introduction, growth, maturity, decline in LQ-45 from the proxy of operational cash flows, investment cash flows, and funding cash flows. This study uses the Analytical Hierarchy Process (AHP) method to see what behavior tends to be used in carrying out shareholding transactions. The results of this study create a behavior model of individual stock investors. Individual stock investors in Indonesia tend to have precision personality types in making stock transaction decisions. This type is a dominant combination, stability, and compliance. The model of individual stock investor behavior starts from making a price target; has a relationship between investors to exchange information related to shares monitored; valuation of shares to be transacted. In addition, the behavior of individual stock investors tends to have accounting information and corporate environmental concerns. Behavioral model Individual stock investors who already have two years or more experience in stock transactions, will have a unique pattern of technical analysis and their own fundamental analysis.
\end{abstract}

Keywords: Investor Behavior; Decision Model; Personalities precisionist; Company life cycle

JEL Classification: G11, M10, M21, M40 


\section{Introduction}

Stock investor behaviour is unique enough to be explored further. There are two major groups of behaviour that have been observed so far. Groups that tend to search for a lot of accounting information and company management which the stock investors are interested to, as well as groups that tend to seek shares momentum that is timely fit to enter or buy the shares of the company. These two groups are often called rational investors and irrational investors. Rational investors often use fundamental analytical tools rather than technical analysis, whereas irrational investors tend to use technical analysis tools rather than fundamental analysis (Natapura, 2009).

The economic Nobel (October 2013) also recognizes the existence of these two different poles. The pole of Efficient Market Theory (Eugene F. Fama) and the pole of Inefficient Market Theory due to financial behaviour (Robert J. Shiller). The Market Efficient Theory provides an emphasis on information which has power (past, present and future information) in taking a decision, if the market provides the information, the market immediately reacts quickly (strong form of efficiency). In the inefficient Market Theory, there are psychological aspects in decision making due to the existence of information bias for individual investors. (Byrne \& Brooks, 2008).

There was a previous research that had been conducted with regard to the behavior of capital market investors. It was about the stock investors who were still considering the annual financial statements issued by issuers in late March or early April as a part of decision making. (Maretha, et al. 2013).

The annual financial statements are still relevant as a part of the decision making of stock investors. This statement was supported by Natapura (2009), Kadariya (2012), Maretha, et all. (2016), in contrast to other studies stated that financial statements were not a part of decision making in investing in the capital market (Septyanto, 2013). Septyanto (2013) stated that the benefits of financial information were insignificant to revise investor's confidence to buy or to sell the shares of the company. The most influential factors are the information from friends, colleagues or family and not directly from the company's performance. This is often called herding behaviour (Banerjee, 2008; Baddeley, 2012).

The differences in viewing the behaviour of individual investor encourage this research to analyse behaviours that often emerge within the individual investors when they make decisions to buy, to sell, or to hold the shares. Therefore, a research was conducted to look at the importance of sectoral selection, particularly on where the company was moving and then entering into 
the company's operational, investment and funding cash flows included in the 45 most liquid stocks on the IDX (LQ-45). The life cycle of the company will start from when the company enters into the start-up stage, moves up to the growth stage, up to the maturity stage, and then gets into the decline stage. All stages are mapped. The company mapping is done by looking at the company's cash flow over the past ten years. Afterwards, the company's life cycle is mapped. The purpose of this research is constructing a behaviour model of the stock investor in deciding the buy-sell-hold of the share.

The research question is how the behaviour of individual investors can make purchases, sales, or hold the stocks when it comes to the life-cycle conditions of the companies that have entered LQ-45 list for the past ten years. The purpose of this study is to develop a model of individual investor behaviour by analysing the hierarchy of decision makers, investors buying, selling, or holding the shares.

This research will create a model that is formed from all types of individual investors, both who have the tendency to be the rational and irrational investors. This is supported by the growth of domestic individual investor data from April 2016 until April 2017 which increased by 41.70 percent in the composition of equity share ownership (shares). This can be seen from the composition in April 2016 that had the figure of Rp169,922.3 billion while the composition in April 2017 had the figure of Rp240,782.12 billion (2017 Capital Market Weekly Statistics). This rapid growth is due to the support of the central government and the Indonesia Stock Exchange (IDX) that launch some programs such as the promotion of "Come, let's have shares saving". It is expected that young investors have good investment behaviour and can also manage their equity portfolio well.

In the previous research (Maretha, et al, 2016), the investor behaviour was studied by adopting the DISC-personality. Investors who became the subject were 88 young investors. Experiments were conducted in three major cities in Indonesia, Semarang, Medan and Manado. The study in those three cities was done because of the positive growth of young investors both in terms of the quantity and the quality. In terms of the quality, in average, the young investors have capital market certification (WPPE-Marketing and Regular). The results obtained from the personality study that was conducted to the individual investors shows that there are 17 personality types from the 25 types that had been carried out by Marston (1893-1947). In DISC personality analysis, it shows that the most shareholders who decided to make sales, purchases, and hold the shares are investors with the type of precisionist and peace maker compared to other types of personality. 
Young investors with precisionist types have a systematic nature that tends to follow the procedures in both personal and business life. They have the quality of self-discipline and have thorough attention to the detail. They always try to be accurate in working and maintaining high standards. Whereas young investors with the peacemaker type are very oriented towards detailed and thorough things. They have a careful and considerate nature before making decisions, and they are consistent in their work. Of the two personality types, it appears that they have almost the same characteristics, namely paying attention to the detail, thorough, and careful in working.

Therefore, it is not surprising that the investors of these two types dominate in deciding to make sales, purchases, and hold the shares because they are sure to do it in detail and are careful as well as having long thought before deciding (Bradberry, 2008). But there are still many young investors who use their emotions rather than their knowledge. The bias of individual investor's behaviour can always occur if the investor does not train his cognitive aspect or emotions well.

Individual investor's behaviour also has the effect of disposition before and after receiving accounting information in the form of financial ratios and the growth of assets, profits, and sales for each year for five years. There is a tendency for individual investors to sell winner shares faster than the loser ones (Maretha, 2013).

The theory used is the Prospect Theory which states that the value function is divided into the value of gains and losses along with the weight of the decision. If the decision is in the area of profit, it will be released more quickly than when it is in the area of loss (Kahneman \& Tversky, 1979, who won the Economics Nobel). The Prospect Theory was developed by the Disposition Effect Theory by Shefrin \& Statman (1985, won the 2013 Economics Nobel) with the Proportion Realized Gain (PGR) and Proportion Realized Loss (PLR). Investors tend to realize a smaller loss than the realization of profits. These investors' biased behaviours are what this research is going to explore by providing information on the company's life cycle and the valuation of the company so that the disruption to the investor's cognition can be reduced by having the information that directly impacts the stock or equity investments decisions. 
Figure1. The Stages of the Industry Life Cycle

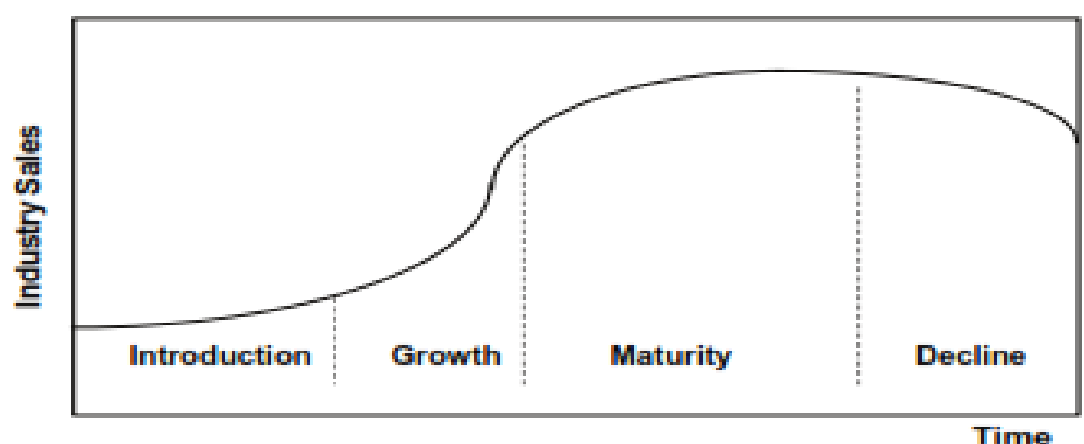

Source: Porter (1980) and Sabol, et al. (2013)

The research in the second year, put more emphasis on the life cycle of the company or the industry. Companies that have been listed on the Stock Exchange have a life cycle that needs to be observed. In Figure 1, it shows that the new company which is listed on the IDX will enter into the introduction stage or startup area. Companies that register at IDX have fulfilled the requirements that IDX continues to monitor as executor and OJK (Financial Services Authority) as approval, so that on the market floor, this stock can be in demand by many people.

Some of the requirements are Rp5 Billion until Rp10 Billion of the net asset value, obtaining WTP (Fit Without Exception) opinion for annual financial report for three consecutive years. Companies after being on the IDX will be monitored continuously by the movement of stakeholders. Thus, the growth will tend to increase towards its growth and maturity. Companies with their respective characteristics can be seen in table 1 . The life cycle evolves starting from the introduction to the growth stage then moving up to the maturity and then it enters to the decline stage. It is expected before entering into the decline stage, the company has done its product development and innovation strategy so that it can revive back to the introduction and growth stage.

Table 1. The Evolution Structure and Industrial Life Cycle

\begin{tabular}{ccccc}
\hline & Introduction & Growth & Maturity & Decline \\
\hline Demand & $\begin{array}{c}\text { Limited to early } \\
\text { adopters: high } \\
\text { income, avant- } \\
\text { grade. }\end{array}$ & $\begin{array}{c}\text { Rapidly } \\
\text { increasing } \\
\text { market } \\
\text { penetration. }\end{array}$ & $\begin{array}{c}\text { Mass market, } \\
\text { replacement/ } \\
\text { repeat buying. } \\
\text { Customers } \\
\text { knowledgeable and } \\
\text { price sensitive. }\end{array}$ & Obsolescence. \\
Technology & $\begin{array}{c}\text { Competing } \\
\text { technologies, }\end{array}$ & $\begin{array}{c}\text { Standardization } \\
\text { around }\end{array}$ & $\begin{array}{c}\text { Trend to } \\
\text { commoditization. }\end{array}$ & $\begin{array}{c}\text { Commodities } \\
\text { the norm: }\end{array}$
\end{tabular}




\begin{tabular}{|c|c|c|c|c|}
\hline & $\begin{array}{c}\text { rapid } \\
\text { productinnovati } \\
\text { on. }\end{array}$ & $\begin{array}{c}\text { dominant } \\
\text { technoloy, rapid } \\
\text { process } \\
\text { innovation }\end{array}$ & $\begin{array}{l}\text { Attempts to } \\
\text { differentiate by } \\
\text { branding, quality, } \\
\text { bundling. }\end{array}$ & $\begin{array}{c}\text { differentiation } \\
\text { difficult and } \\
\text { unprofitable. }\end{array}$ \\
\hline Products & $\begin{array}{l}\text { Short } \\
\text { production } \\
\text { runs, high } \\
\text { skilled labor } \\
\text { content, } \\
\text { s[eciallized } \\
\text { distribution } \\
\text { channels. }\end{array}$ & $\begin{array}{c}\text { Capacity } \\
\text { shortages, mass } \\
\text { production, } \\
\text { competition for } \\
\text { distribution. }\end{array}$ & $\begin{array}{l}\text { Emergemce of } \\
\text { overcapacity, } \\
\text { deskilling of } \\
\text { production, long } \\
\text { production runs, } \\
\text { distributioncarry } \\
\text { fewer lines. }\end{array}$ & $\begin{array}{l}\text { Chronic } \\
\text { overcapacity, } \\
\text { re-emergence } \\
\text { of specialty } \\
\text { channels. }\end{array}$ \\
\hline $\begin{array}{c}\text { Manufacturing } \\
\text { and } \\
\text { Distribiution }\end{array}$ & $\begin{array}{l}\text { Short } \\
\text { production } \\
\text { runs, high } \\
\text { skilled labor } \\
\text { content, } \\
\text { seciallized } \\
\text { distribution } \\
\text { channels. }\end{array}$ & $\begin{array}{l}\text { Capacity } \\
\text { shortages mass } \\
\text { production, } \\
\text { competition for } \\
\text { distribution. }\end{array}$ & $\begin{array}{l}\text { Emergence of } \\
\text { overcapacity, } \\
\text { deskilling of } \\
\text { production, long } \\
\text { production runs } \\
\text { distribution acrry } \\
\text { fewer lines. }\end{array}$ & $\begin{array}{l}\text { Chronic } \\
\text { overcapacity, } \\
\text { reemergence } \\
\text { of specially } \\
\text { channels. }\end{array}$ \\
\hline Trade & $\begin{array}{l}\text { Producers and } \\
\text { consumers in } \\
\text { advanced } \\
\text { countries. }\end{array}$ & $\begin{array}{l}\text { Exports from } \\
\text { advanced } \\
\text { country to rest } \\
\text { of the world. }\end{array}$ & $\begin{array}{c}\text { Production shifts to } \\
\text { newly } \\
\text { industrializing then } \\
\text { developing } \\
\text { countries, }\end{array}$ & $\begin{array}{l}\text { Export from } \\
\text { countries with } \\
\text { lowest labor } \\
\text { costs. }\end{array}$ \\
\hline Competition & Few companies. & $\begin{array}{l}\text { Entry. ,ergers } \\
\text { and exits. }\end{array}$ & $\begin{array}{l}\text { Shakeout, proce } \\
\text { competition } \\
\text { increases. }\end{array}$ & $\begin{array}{l}\text { Price wars, } \\
\text { exits. }\end{array}$ \\
\hline $\begin{array}{l}\text { Key success } \\
\text { factors }\end{array}$ & $\begin{array}{l}\text { Produts } \\
\text { innovations, } \\
\text { establishing } \\
\text { credible image } \\
\text { of firn and } \\
\text { product }\end{array}$ & $\begin{array}{l}\text { Design for } \\
\text { manufacture, } \\
\text { access to } \\
\text { distribuion, } \\
\text { brand building, } \\
\text { fast product } \\
\text { development, } \\
\text { process } \\
\text { inovation. }\end{array}$ & $\begin{array}{l}\text { Cost efficiency } \\
\text { through, capital } \\
\text { intensity, scale } \\
\text { effocoency, and } \\
\text { low input costs. }\end{array}$ & $\begin{array}{c}\text { Low } \\
\text { overheade, } \\
\text { buyer } \\
\text { selesction. } \\
\text { Signalling } \\
\text { commitment, } \\
\text { rationalizing } \\
\text { capacity. }\end{array}$ \\
\hline
\end{tabular}

The relationship of the cash flow and the company life cycle according to Prihadi (2010) can be explained as follows: when a company is established, obtained funds from the owner and creditor, bought the assets and started its operations, it will be considered in the Start-up stage. If the company expands its market and has product diversification, it will increase its asset base and source of income, and will increase costs.

This stage is considered as the developing stage of the company. If the company has achieved market stability, products and income, experienced tighter 
competition, conducted business restructuring to increase profits and to reduce costs, the company is considered in the maturity stage. If the company experiences a market contraction and the demand of the product starts to decrease, experiences a decrease in income and profit, so that the company has to sell the investment, then the company is considered in the decline stage.

There are theories which are able to measure personality. One of them is the theory that is brought up by William Moulton (Bradberry, 2007). In the early 20s, Marston wrote a book of Psychology, Emotions and Behaviour, and then in 1928 he wrote the book "The Emotion of Normal People" which became the forerunner of the DISC model. According to Marston's theory, a person will be motivated by four intrinsic drives that direct the pattern of behaviour represented by four letters of the alphabet:

1) $D$ (Dominance), related to control, power and assertiveness;

2) Influence (I) deals with the individual approach to social situations, and their communication styles;

3) Steadiness $(S)$ is a factor of patience, perseverance and attention;

4) Compliance (C) describes a person's approach to structure and organization (Bradberry, 2007).

The DISC is used to express behavioural traits and behavioural trends of a person in a particular environment. Personality based on DISC profile is a behaviour based on stimulus and response where everyone will behave differently to the response obtained.

\section{Methodology}

This study uses analytical hierarchy process (AHP) for each criterion that is examined. AHP is used to achieve the goal of this research by reducing the behavior bias of individual investors when buying, selling, or holding shares. AHP is very suitable with the decision making process that can be made in stages. Each criterion has a different hierarchy for its continuous approach. The AHP process as a whole has the following stages:

(1) Creating a hierarchy model to be questioned;

(2) Setting priorities by providing criteria for each level (table 2);

(3) Measuring consistency;

(4) Evaluating consistency where $C R<0.1$. 
Table 2. AHP PROCESS

\begin{tabular}{|c|c|c|c|c|}
\hline \multicolumn{2}{|r|}{ Criteria Description } & \multirow{2}{*}{\multicolumn{2}{|c|}{ Objective: }} & \multirow{2}{*}{$\begin{array}{l}\text { DM BUY-SELL-HOLD STOCK BUMN, } \\
\text { BUMD, \& SWASTA }\end{array}$} \\
\hline \multirow[t]{2}{*}{1} & \multirow{3}{*}{$\begin{array}{l}\text { Both elements are } \\
\text { equally important } \\
\text { One element is a little bit } \\
\text { more important than the } \\
\text { other one }\end{array}$} & & & \\
\hline & & Criteria: & 1 & $\begin{array}{l}\text { The Behaviour of Targeted Investor } \\
\text { \&Accuracy }\end{array}$ \\
\hline 3 & & & 2 & $\begin{array}{l}\text { Investor Behaviour, Relationship \& } \\
\text { Self-Assessment }\end{array}$ \\
\hline \multirow[t]{2}{*}{5} & One element is more & & & Investor Behaviour, Choosing \\
\hline & $\begin{array}{l}\text { important than the other } \\
\text { one }\end{array}$ & & 3 & $\begin{array}{l}\text { Information \& Surrounding } \\
\text { Environment }\end{array}$ \\
\hline \multirow[t]{2}{*}{7} & One element is far more & & 4 & Technical Analysis Behaviour \\
\hline & $\begin{array}{l}\text { important than the other } \\
\text { one }\end{array}$ & & 5 & Fundamental Analysis Behaviour \\
\hline 9 & $\begin{array}{l}\text { Absolutely more } \\
\text { important }\end{array}$ & & & \\
\hline $2,4,6,8$ & $\begin{array}{l}\text { The mean value between } \\
\text { two adjacent opinions }\end{array}$ & & & \\
\hline
\end{tabular}

\section{Business Cycle}

The mapping results from cash flows show the companies that entered the LQ-45 for the last 10 years have a Strat-Up Business Cycle to Growth, then Growth to Maturity, and Maturity to Growth or the reverse. This indicates that these companies have operational and net profits that are always positive. While investment and funding cash flows always have different signs, unless they enter the decline area, all directions are positive for both CFO, CFI and CFF. This result is supported by previous studies Sabol, et al. (2013).

Figure 2. LQ-45 Business Cycle (2008-2016)

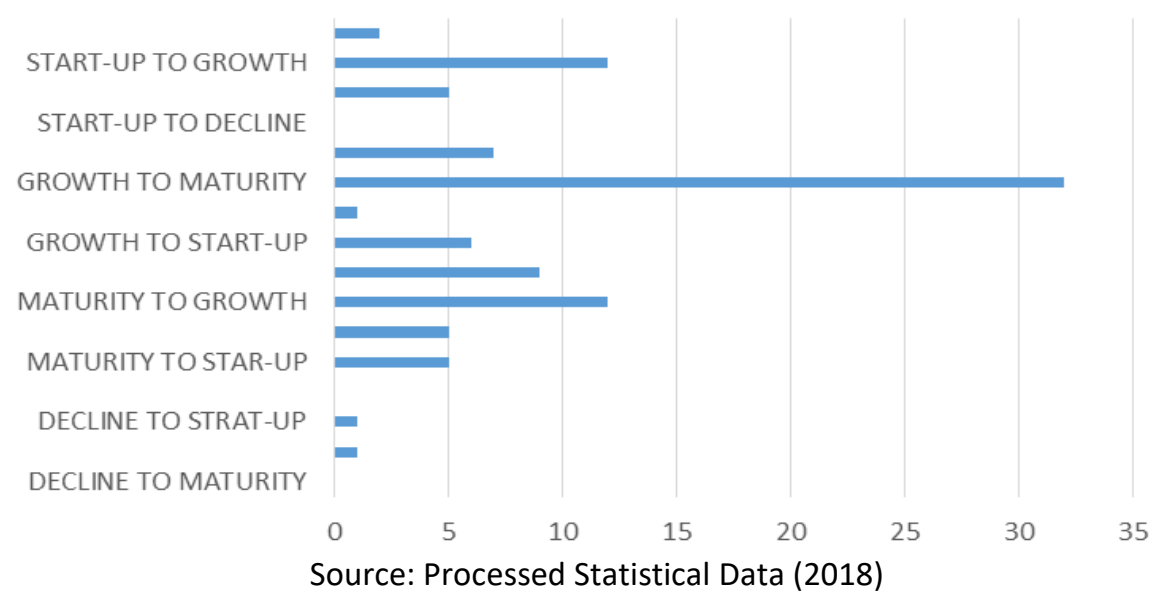


Figure 3 shows the difference in age with firm value, when the company is still operating (1-5 years) the company's value is seen by the market (PBV) at a price that is still the same as the price at the IPO. When passing from 5-13 years, the company starts to be seen by investors, so prices can rise (positive) and decrease (negative). In other words, the stages of growth and decline can occur in this age range.

However, if the company can study for 13 years from the start of the company conducting an IPO, and can pass through the company's external problems, then the company can return to the start-up phase, growth, maturity and return to decline at the age of 23.d. 28 years, if it does not show innovations or new things, the company will experience bankruptcy from a market perspective. How from the perspective of the company's internal performance, in this case represented by ROA and ROE?

Figure 3. Age and Company Value

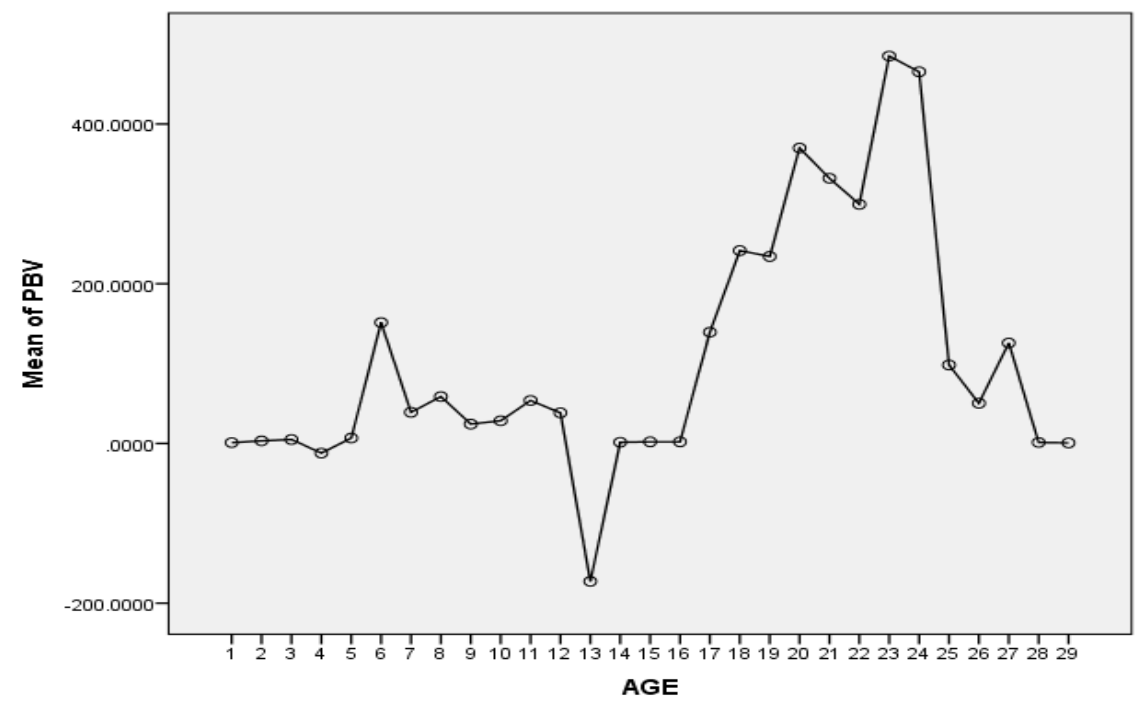

Source: Processed Statistical Data (2018)

Figure 3 shows the benefits obtained from the management of total assets can occur when the company succeeds through decline, aged 13-14 years after the IPO, it appears that ROA is in the range of $2 \mathrm{~s} .8$ percent. This shows that the company can manage the total assets very optimally, so that the decline that previously occurred can be covered by profits 2 years later.

Two years later at the age of 17-19 years the company again obtained optimum total asset management. It's just that when a company can carry out 
internal performance seen from the distribution of net profit divided by total assets, it should be accompanied by good total asset performance (TATO), so that current assets can generate money because sales (accounts receivable and inventory) can support cash and cash equivalents are better.

The faster it rotates, the shorter the inventory can turn into cash or receivables. This is due to high sales followed by the effective collection of accounts receivable and the reduction of uncollectible accounts.

Figure 4. Age, ROA and TATO of the Company
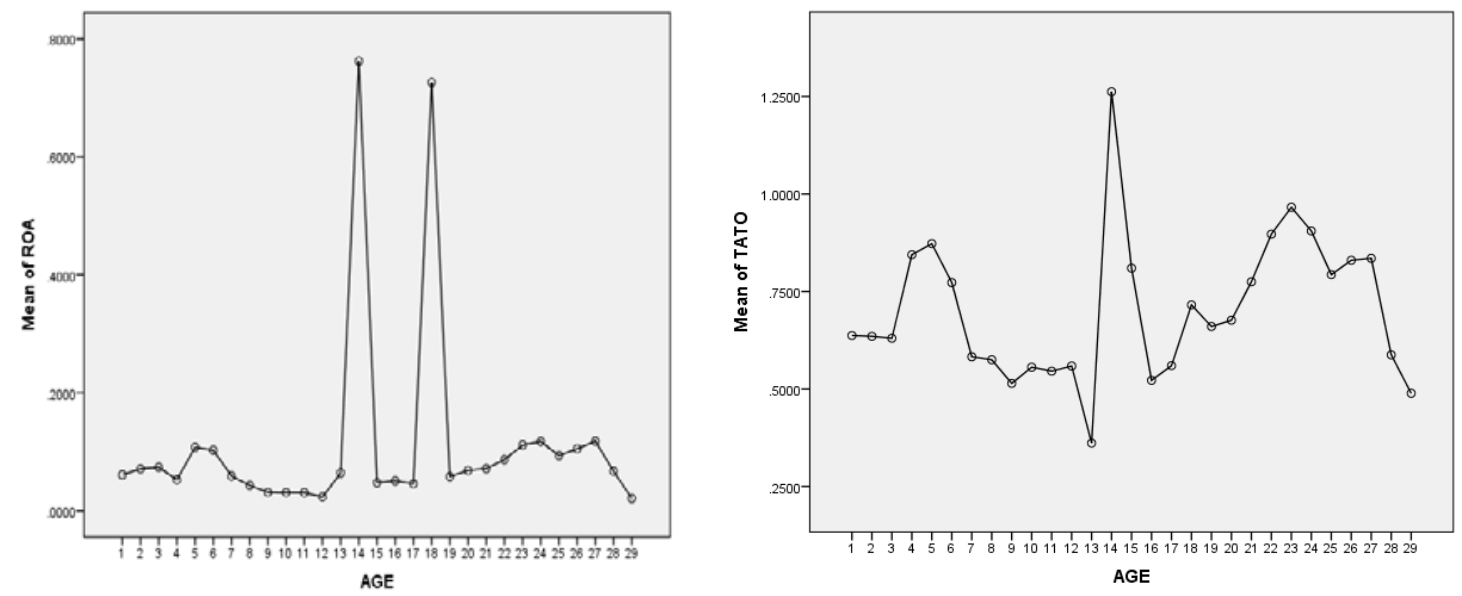

Source: Processed Statistical Data (2018)

Figure 4 shows the return of equity and the ratio of total liabilities to equity. When the company is 13-14 years after the IPO, the company can obtain optimal ROE, but after that the movement is stable again before before age 1314 , the company is very volatile in managing its equity.

Comparison of liabilities with equity is very volatile as well before the age of 13-14 years after the IPO, compared to the end. This shows that in the beginning there were still many debts to be settled, after the age of 13-14 years after the IPO, the company could develop its external funding from the sale of shares or other corporate actions.

Therefore companies with the ability to generate profits by managing their equity should be accompanied by good corporate liquidity performance. 
Figure 5. Company Age, ROE and DER
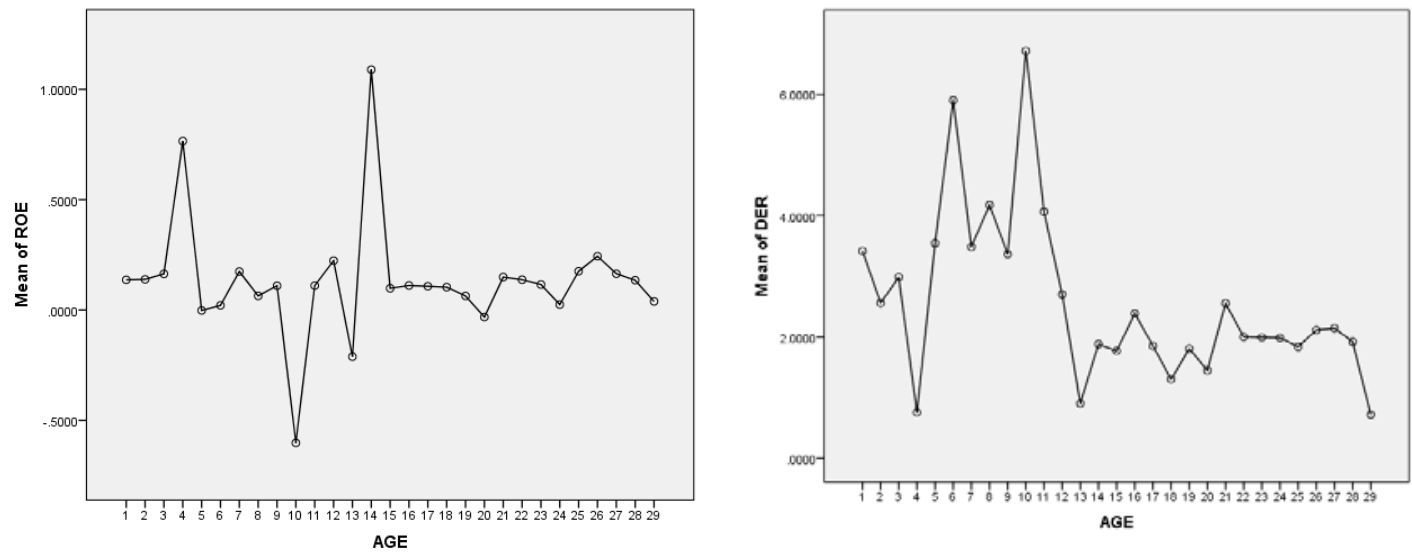

Source: Processed Statistical Data (2018)

Table 5, the liquidity ratio (Quick Ratio) shows that the comparison of cash and cash equivalents with its smooth debt is capable of making smooth payments. This is supported by a fluctuating working capital ratio, but at the age of 13 and 14 years, the working capital ratio reaches the optimum value. The ratio of working capital here appears to be greater current assets and smaller current liabilities, changing to long-term liabilities. This shows that the company is owned to reduce the liability for liabilities. This study also looked at the company's cash flow as an indicator of the company's ability to produce cash and cash equivalents, see liquidity, solvability, and causes of differences between current period net income (accrual basis) and net cash flows generated by operating activities (cash basis). Besides that, you can also see financial transactions related to investment and funding. In PSAK 2 (revised 2009), cash reports are grouped into three types of activities, namely operating activities, funding activities, and investment activities.

Figure 6. Age, Liquidity, and Working Capital of the Company
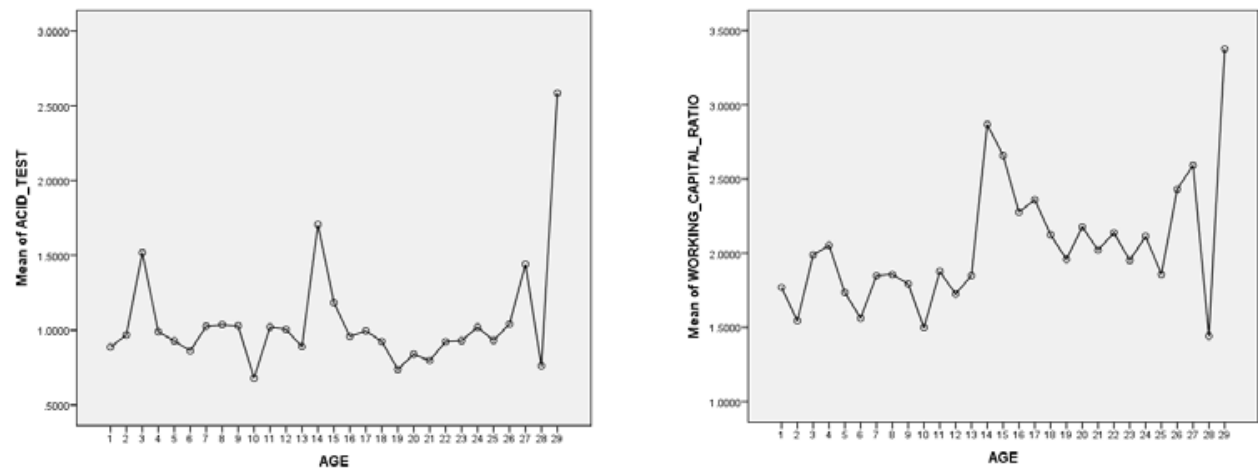

Source: Processed Statistical Data (2018) 
Third, cash flow activity, we can see the age of 13-27 years old after the IPO, forming a rising trend line. That is, the greater the cash inflows from the roar of goods or services and the higher interest income, dividend income, and rental income. However, at the age of 27-29 years the company after the IPO thought more about investment and increased costs incurred for operational costs, loan interest payments, tax payments, and other expenses.

Figure 7. Age and CF of Company Operations

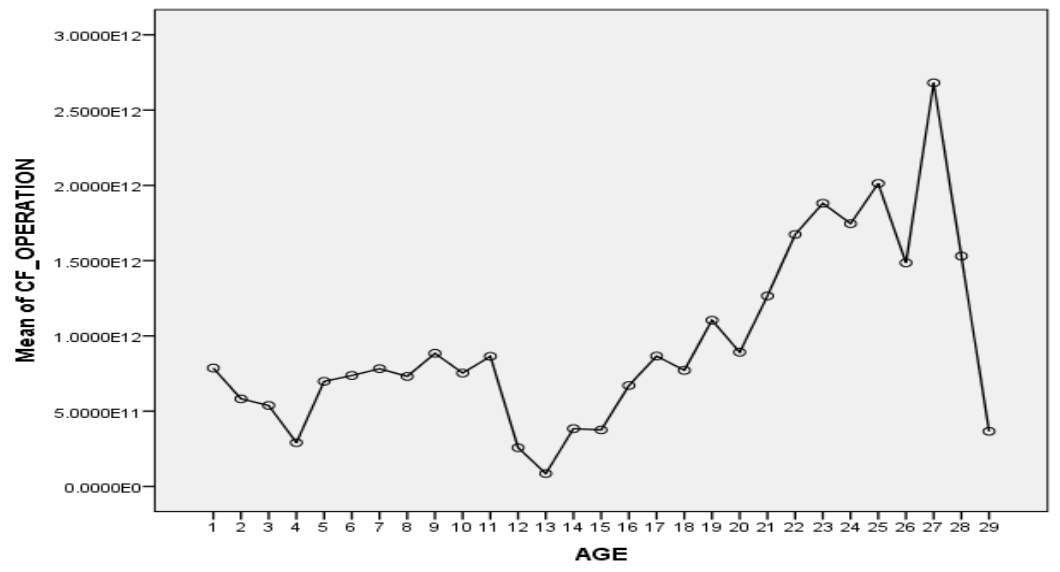

Source: Processed Statistical Data (2018)

In the investment cash flow activity, it can be seen that Figure 7 has a fluctuating downward trend. Age 1-5 years after the IPO, the company still has positive investment cash, meaning cash inflows from sales of fixed assets, intangible assets, sales of shares of other entities owned as investments, payment of principal to other entities, and receipt of interest income, dividend income and rental income is still higher than cash outflows such as the purchase of intangible assets and assets, purchase of other entity stock investments, lending to other entities, and all investment expenditures.

Figure 8. Age and CF-Investment and CF-Financing of Companies
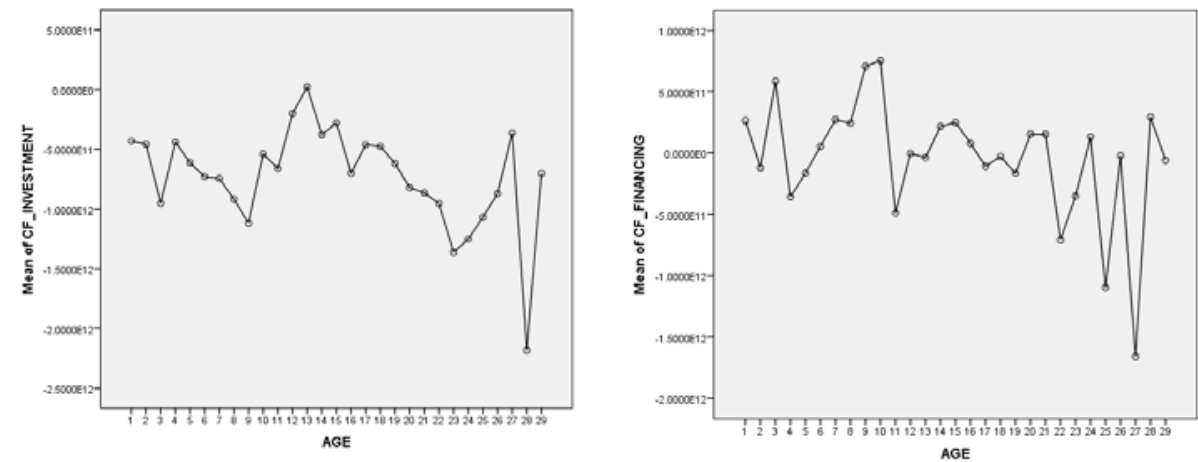

Source: Processed Statistical Data (2018) 
In Figure 7 and Figure 8, it appears that the pattern is the opposite, meaning that activities at the age of 1-5 companies after the IPO invests and has an impact on funding activities. This means that companies make investment decisions based on funding (issuance of shares as additional paid-in capital, bond debt, reduce outstanding shares, repay the principal, pay dividends to shareholders) that can support investment activities (purchase of fixed assets, investment in other entities, lending to other entities) and operations (raw material purchases, operating expenses, tax payments, and other expenses) of the company.

\section{AHP results}

The next step, after knowing the business cycle of each issuer that entered the LQ-45 Index (2008-2016), the researcher conducted a Focus Discuss Group (FGD) about investor behaviour in the city of Semarang. The FGD results are included in the AHP analyst.

As for the rarities as follows: Before getting the AHP results as above, the process is mathematically carried out normalization first, then the consistency test of the sequences that have been filtered out of the validation and reliability of the distributed questionnaire is carried out and cross-check with the FGD is done. Investors and branch managers of securities in the city of Semarang.

The above stages are carried out repeatedly in accordance with criteria that have been filtered out of various stages (secondary data cycle of business cycle, questionnaire, and FGD). Therefore, the results of the various stages are shown in the table below. Table 5.3 is a decision model that has been tested to consistency. The FGD participants and other supporting data made this model acceptable by Hirerical Process Analysis (AHP).

Besides that, the decision to invest by individual investors is also based on knowledge of the risks borne and the returns to be obtained. These two things make a difference in the decision to invest in which shares and which shares to sell. The researcher gives a description of the decision model as follows: 
Figure 9. Process of Buying-Selling-Holding Individual Investor Shares

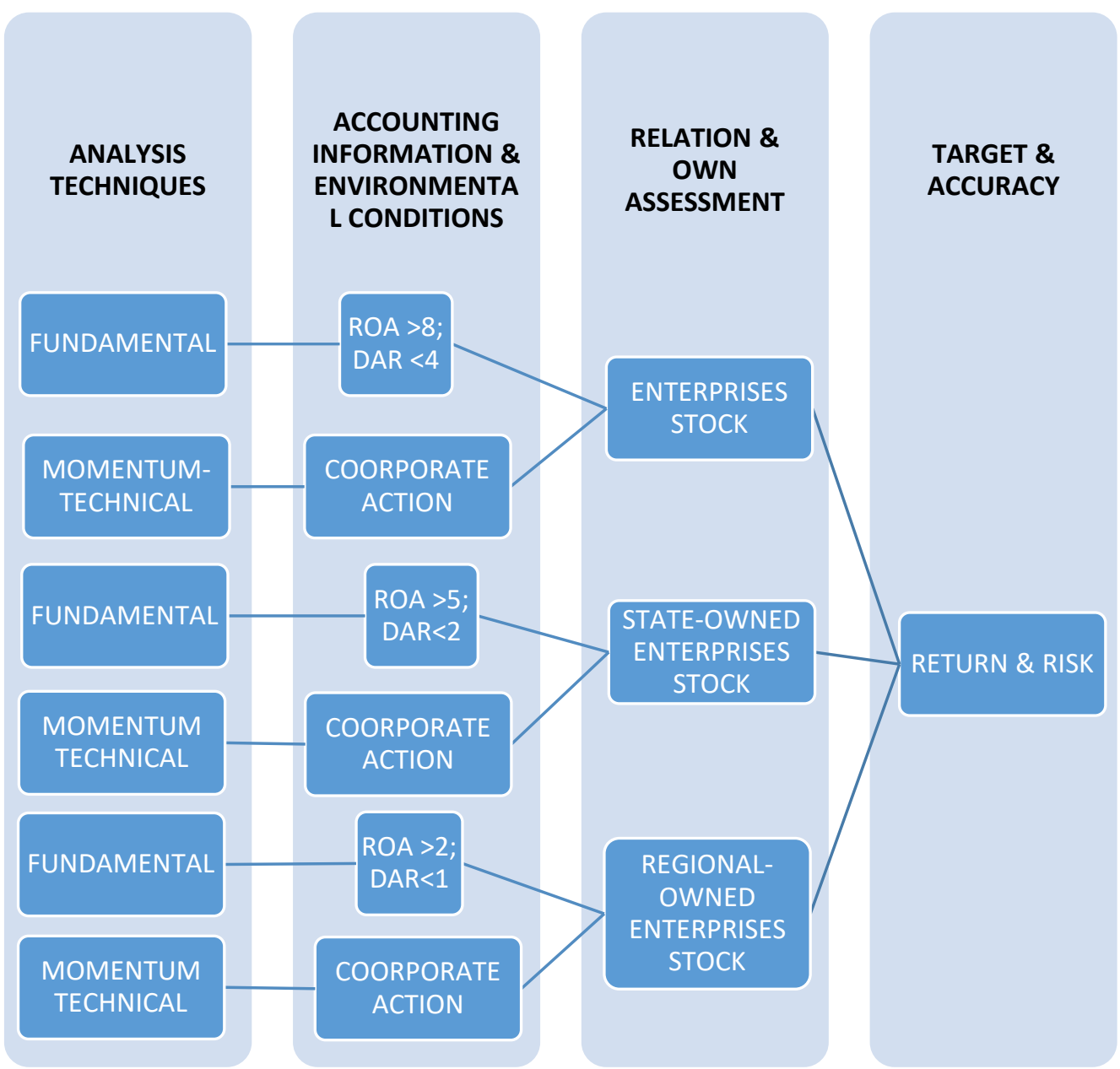

In figure 9, each stage is evaluated, if it is not in accordance with the target and the techniques used are not too accurate, an analysis technique can be evaluated.

\section{Conclusion}

Individual stock investor's behaviour is very diverse in making transaction patterns, but the same pattern of individual stock investors makes decisions by having a target both to obtain returns and risks that will be borne in making decisions to buy, sell or hold. After that, the next behaviour tends to be individual stock investors having relations with other investors or stock observers to be invited to discuss, even though they already have their own assessors of the shares 
they are trading. Other behaviours that are not less important are that individual stock investors also understand the accounting information of the issuers they will translate, only they often see earnings per share, net income, and the proportion of total debt to the total equity of the issuer.

AHP has sorted the process of making decisions to buy, to sell, and to hold shares caused by behaviour that is resulted from the investors' personalities. At the next stage, it produces behaviours in both technical and fundamental analyses that are often carried out by individual stock investors. In the behaviour in making decisions using technical analysis, individual stock investors often use moving average (MA) transactions of 20 days and 50 days, meaning that the intersection between the two will often make a decision to buy or sell shares. Whereas when using fundamental analysis, individual stock investors tend to look at financial risk over the past 3 years, the fair value of their shares, the proportion of debt to equity, and the efficiency of managers in managing their company's operations.

\section{Acknowledgement}

Thank you for the Grant from the Republic of Indonesia Ministry of Research, Technology and Higher Education for Competency-Based Research (PKB) with the 2018 fiscal year research contract.

\section{References}

[1] Baddeley. A. (2012). Working Memory: Theories, Models, and Controversies. Annual Review of Psychology, 63, pp.1-29.

[2] Banerjee, SB. (2008). Corporate social responsibility: The Good, The Bad and The Ugly. Critical Sociology, 34(1), pp. 51-79.

[3] Bradberry, T. (2007). The Personality Code. Yogyakarta: WangunPrintika.

[4] Byrne, A., \& Brooks. M. (2008). Behavioral Finance: Theories and Evidence. The Research Foundation of CFA Institute Literature Review.

[5] BEI. (2017). Data Statistik Mingguan Pasar Modal.

[6] Kadariya, S. (2012). Factors affecting investor decision making: A case of Nepalese capital market. Journal of Research in Economics and International Finance, Vol. 1(1), pp. 16-30.

[7] Kahneman, D. \& Tversky, A. (1979). Prospect Theory: An Analysis of Decision Under Risk. Econometrica, Vol. 47, No. 2, pp. 263-293.

[8] Maretha, E. L. (2013). Perilaku Investor Individu dalam Pembuatan KeputusanI nvestasi Saham: Efek Disposisi dan Informasi Akuntansi. JurnalOrganisasidanManajemen, Vol.9. 1 Maret 2013, pp. 31-53.

[9] Maretha, E. L., Haryanti, K. \& Sasmito, Y. W. (2016). Perilaku Investor IndividuberdasarkanPortofoiodan DISC-Personality di Pasar Modal Indonesia. Prosiding Seminar Nasional APMMI-Disruptive Innovation.

[10] Natapura, C. (2009). Analisis Perilaku Investor Institusional dengan Pendekatan Analytical Hierarchy Process (AHP). Jurnal Ilmu Administrasi dan Organisasi, Sept-Des, Vol.16, No.3, pp. 180-187. 
[11] Palepu, K. G., Healy, P. M. \& Erik Peek. (2010). Business Analysis and Valuation: IFRS Edition; SOUTH-WESTERN CENGAGE Learning.

[12] Porter, M.E. 1980. Porter, M. E. (1980). Competitive Strategy: Techniques for Analyzing Indstries and Competitors, The Free Press.

[13] Prihadi, T. (2010). AnalisisLaporanKeuangan: TeoridanAplikasi. PPM-Jakarta.

[14] Septyanto (2013). Faktor-Faktor yang mempengaruhi Investor Indvidu dalam Pengambilan Keputusan Investasi Sekuritas di Bursa Efek Indonesia (BEI). Jurnal Ekonomi, Vol. 4 No.2 November.

[15] Shefrin, H., \& Statman, M. (1985). The Disposition to Sell Winners Too Early and Ride Losers Too Long: Theory and Evidence. The Journal of Finance. Vol. 40, No. 3, pp. 777-790.

[16] Sabol, A., M. Sander, \& D. Fuckan. (2013). The Concept of Industry Life Cyle and Development of Business Strategies, pp. 635-642.

\section{APPENDIX: Decision Making Model}

\begin{tabular}{|c|c|c|}
\hline F1 & \multicolumn{2}{|c|}{ DM BASE ON TARGET \& ACCURACY } \\
\hline 9 & BTA14 & Trying to reach the target in as planned \\
\hline 7 & BTA15 & Having accuracy in doing the main work \\
\hline 5 & BTA13 & Having high accuracy standards in working on transactions \\
\hline 3 & BTA16 & Liking the environment with less clear rules so that it can be flexible \\
\hline F2 & \multicolumn{2}{|r|}{ DM BASE ON RELATION \& SELF JUGMENT } \\
\hline 9 & RSJ03 & $\begin{array}{l}\text { Feeling anxious when making decisions that have a negative impact on } \\
\text { others }\end{array}$ \\
\hline 5 & RSJ02 & Thinking back to the decision if something is wrong \\
\hline 5 & RSJ10 & Linking to confront \\
\hline F3 & \multicolumn{2}{|c|}{ DM BASE ON ACCOUNTING INFORMATION \& ENVIROMENT CONDITION } \\
\hline 9 & AIECO4 & Loving a safe work environment \\
\hline 7 & AIEC2 & Having details and liking to look at things in their environment \\
\hline 5 & AIEC30 & $\begin{array}{l}\text { Buying shares because they understand the Accounting Information of } \\
\text { the shares }\end{array}$ \\
\hline 3 & AIEC20 & Liking the sudden change \\
\hline F4 & \multicolumn{2}{|c|}{ TECHNICAL ANALYSIS } \\
\hline 9 & AT07 & $\begin{array}{l}\text { The intersection of the line, where the } 20 \mathrm{MA} \text { is below the } 50 \mathrm{MA} \text {, the } \\
\text { decision is to sell shares because the price moves down }\end{array}$ \\
\hline 7 & AF02 & $\begin{array}{l}\text { When choosing stocks, the working capital owned by the company is not } \\
\text { considered }\end{array}$ \\
\hline 5 & AT09 & $\begin{array}{l}\text { The line intersection, where the MA } 20 \text { is above the } 50 \mathrm{MA} \text {, then the } \\
\text { decision is to buy the stock as the price moves up }\end{array}$ \\
\hline F5 & \multicolumn{2}{|r|}{ FUNDAMENTAL ANALYSIS (FA) } \\
\hline 9 & FA06 & $\begin{array}{l}\text { Stock selection tends to see the level of corporate financial risk of the } \\
\text { last } 3 \text { years }\end{array}$ \\
\hline 7 & FA18 & $\begin{array}{l}\text { The decision is to sell shares when the intrinsic price (fair) is less than } \\
\text { the market price (overvalue) }\end{array}$ \\
\hline 5 & FA04 & $\begin{array}{l}\text { The company chosen for stock investment has a proportion of long-term } \\
\text { debt that is smaller than its equity }\end{array}$ \\
\hline 3 & FA07 & $\begin{array}{l}\text { The decision to buy a stock looks at how efficient managers are in } \\
\text { managing their operations. }\end{array}$ \\
\hline
\end{tabular}

